Eur J Clin Chem Clin Biochem

1995; 33:673-677

(c) 1995 Walter de Gruyter \& Co.

Berlin - New York

\title{
Effect of Sodium Valproate on Renal Cell Brush-Border Enzymes in Rats
}

\author{
By Ivana Čepelak ${ }^{1}$, Branka Rekić ${ }^{3}$, Dubravka Juretić ${ }^{1}$ and Anka Mandušić ${ }^{1}$ \\ ${ }^{1}$ Institute of Medical Biochemistry, School of Pharmacy and Biochemistry, University of Zagreb, Zagreb, Croatia \\ 2 Split University Hospital, Split, Croatia \\ 3 Ina GP Unit, Zagreb, Croatia
}

(Received November 21, 1994/March 26, 1995)

Summary: The effect of sodium valproate $(200 \mathrm{mg} / \mathrm{kg}$ body weight) on renal cells was investigated during a 10day trial, by determining the catalytic activities of alanine aminopeptidase, $\gamma$-glutamyltransferase and alkaline phosphatase in the membrane cell brush-border of the renal proximal tubules.

Four days after the administration of sodium valproate, a significant increase was observed in the volume of urine ( $9.2 \pm 4.2 \mathrm{ml} / 18$-h volume; control group, $3.06 \pm 1.8 \mathrm{ml} / 18 \mathrm{~h}$ volume), and in the catalytic activities of $\gamma$ glutamyltransferase (2.69 times that measured in the control group) and alkaline phosphatase (3.02 times that measured in the control group) in urine. After prolonged treatment the urine became alkaline ( $\mathrm{pH}=10.5$ on day 10 ), thereby excluding alanine aminopeptidase as a useful indicator of renal cell changes following the administration of sodium valproate. The activities of alkaline phosphatase and $\gamma$-glutamyltransferase in isolated vesicles of renal brush-border membrane cells were significantly increased $(p<0.05)$ and decreased, respectively.

On the basis of the results obtained, we believe that the determination of the catalytic activities of $\gamma$-glutamyltransferase and alkaline phosphatase in urine might prove useful for the follow-up of the renal cell state during therapy with sodium valproate.

\section{Introduction}

Sodium valproate (sodium dipropyl acetate) is an antiepileptic which has a number of side effects, such as gastrointestinal discomforts, pancreatitis, body weight gain, hyperglycinaemia and hyperglycinuria, changes of coagulation, etc. (1). In quite a number of adult patients and especially in children, the administration of sodium valproate is also associated with the development of acute $(2,3)$ or chronic hyperammonaemia $(4,5)$. The genesis of hyperammonaemia has not yet been fully explained, but two mechanisms have attracted particular attention: decreased ammonium detoxification via urea synthesis in the liver (6), and increased glutamine metabolism and increased ammonium synthesis in the kidney (7-9). Cases of serious renal damage, such as interstitial nephritis (10) and proximal renal tubule dysfunction (11) have also been reported following sodium valproate therapy.
Considering the numerous metabolic effects of sodium valproate (12), especially on the metabolism of fatty acids, it may also conceivably disturb the integrity or function of the renal cell membrane. On the other hand, increased catalytic activities of some renal enzymes in urine (otherwise localized on the cell membrane of the renal proximal tubules) are known to be among the earliest indicators of kidney cell pathologic alterations (13).

Therefore, the effect of sodium valproate on rat kidney cells was followed by monitoring the catalytic activities of alanine aminopeptidase ${ }^{1}$ ), alkaline phosphatase ${ }^{1}$ ) and $\gamma$-glutamyltransferase ${ }^{l}$ ) in urine and isolated brush-border membrane vesicles of the renal proximal tubules.

\footnotetext{
1) Enzymes:

Alanine aminopeptidase, EC 3.4.11.2

Alkaline phosphatase, EC 3.1.3.1

$\gamma$-Glutamyltransferase, EC 2.3.2.2
} 


\section{Materials and Methods}

\section{Material}

The study was performed on male Fisher rats $(n=29)$ aged 1 month, mean body weight $100 \mathrm{~g}$. The animals had free access to chow and water throughout the study. The animals were divided into four groups: the control group $(n=6)$ received $1 \mathrm{ml}$ saline $(0.154 \mathrm{~mol} / 1 \mathrm{NaCl})$ daily per os. The experimental group $(n=23)$ received $200 \mathrm{mg} / \mathrm{kg}$ body weight sodium valproate daily per os in the same volume. Experimental animals were sacrificed by severing the cranial spine on day $1(n=8)$, day $4(n=7)$ and day $10(n=8)$.

Prior to sacrifice, the 18-h urine was collected in metabolic cages for each group of animals. Urine volume and $\mathrm{pH}$ were readily determined by test strips. Urine was tested for the presence of protein, glucose, haemoglobin and ketone bodies, and centrifuged at 1500 $\mathrm{min}^{-1}$ for $10 \mathrm{~min}$ in a Tehnica LC 320 laboratory centrifuge. Dialysis (PM exclusion 12000-14 000), PolyLabo, Strasbourg, France) was performed against water for $3 \mathrm{~h}$ to remove possible enzyme inhibitors. Catalytic activities of the enzymes were then readily determined in the dialysed urine samples.

After sacrificing animals under ether narcosis on day 1, 4 and 10, blood was withdrawn from the umbilical vein. Blood serum was separated by centrifugation at $3000 \mathrm{~min}^{-1}$ for $10 \mathrm{~min}$ and serum urea concentration was determined.

Immediately after sacrifice, the kidneys were excised, washed in cold saline, dried with filter paper and freed from the connective tissue and capsules.

Renal cortex sections prepared with a microtome were minced, placed in $15 \mathrm{ml}$ buffer (Tris- $\mathrm{HCl}, 12 \mathrm{mmol} / \mathrm{l}, \mathrm{pH}=7.4$; EGTA, $5 \mathrm{mmol} / \mathrm{l}$; mannitol, $300 \mathrm{mmol} / \mathrm{l}$ ), then homogenized with an Ultra Turrax homogenizer, type 18-10 (Janke \& Kunkel, GK). Brush border membrane vesicles were isolated by precipitation with $\mathrm{Mg}$ ions, according to Biber et al. (14), using a Beckman L5-65 ultracentrifuge. Protein concentration and catalytic activities of alanine aminopeptidase, alkaline phosphatase and $\gamma$-glutamyltransferase were determined in isolated brush-border membrane vesicles. Mean values of the factor of enzymatic activity enrichment, following brush border membrane vesicle isolation, were $f=11.0$, $f=8.0$ and $f=10.0$ for alanine aminopeptidase, alkaline phosphatase and $\gamma$-glutamyltransferase, respectively.

\section{Methods}

The catalytic activity of alanine aminopeptidase was determined by the procedure of Haschen (15) on a Pye Unicam SP-6-550 UV/ VIS spectrophotometer, that of alkaline phosphatase by the procedure of $M c C o m b$ \& Bowers (16), and that of $\gamma$-glutamyltransferase by the procedure of Szász et al. (17) on a Centrifichem 400 autoanalyser. Serum urea concentration was determined by the method of Sampson et al. (18) on a Centrifichem 400 autoanalyser. The protein concentration of isolated brush-border membrane vesicle preparations was determined by the procedure of Bradford et al. (19) on a Pye Unicam SP-6-550 UV/VIS spectrophotometer.

\section{Chemicals}

Commercial test kits for alkaline phosphatase, $\gamma$-glutamyltransferase and urea were obtained from Herbos, Sisak, manufactured in cooperation with SKI (Smith \& Kline Instruments, Inc. USA). EGTA, Fluka; HEPES and $D L$-alanine- $\beta$-naphthylamide $\cdot \mathrm{HCl}$, Sigma; and all other chemicals of analytical purity were obtained from Kemika, Zagreb.

The statistical significance of changes in enzyme catalytic activities in the experimental group samples, compared with those in control animals, were analysed by Student's t test for small samples (20).

\section{Results}

Prior to the determination of enzyme catalytic activities in the samples, an in vitro experiment performed on pool serum showed that sodium valproate caused no significant interference in the determination of alanine aminopeptidase, alkaline phosphatase and $\gamma$-glutamyltransferase catalytic activities.

A routine urine analysis was performed to test kidney function. Protein, glucose, ketone bodies and haemoglobin appeared to be normal in all groups of animals. Moreover, the concentration of urea in serum as well as the concentration of protein in kidney brush border membrane vesicles did not change throughout the experiment.

After four days of sodium valproate administration, the 18-h urine volume was significantly increased $(9.2$ $\pm 4.2 \mathrm{ml}$ ) in comparison with the control group (3.06 $\pm 1.8 \mathrm{ml})(\mathrm{p}<0.05)$; urine $\mathrm{pH}$ was markedly increased to 10.5 after 10 days of sodium valproate administration (control group, $\mathrm{pH}=6.0$ ) (tab. 1).

Changes in the enzyme catalytic activities in 18-h urine samples and isolated renal brush-border membrane vesicles are shown in figures 1,2 and 3 . On day 1 of the administration of sodium valproate, only the catalytic activity of alanine aminopeptidase in urine was increased significantly ( 2.0 times that found in the control group; $p<0.05$ ) (fig. 1). The enzyme activity gradually decreased, attaining control group values on day 10. In isolated renal brush-border membrane vesicles, the alanine aminopeptidase activity showed a significant change only on day 1 of the experiment.

The catalytic activities of $\gamma$-glutamyltransferase and alkaline phosphatase in the urine of experimental animals were significantly increased on day 4 of sodium valproate administration ( $\gamma$-glutamyltransferase, 2.69 -fold, $\mathrm{p}<0.05$; alkaline phosphatase, 3.02-fold, $\mathrm{p}<0.001$ ) (figs. 2 and 3). On day 10 of the treatment, the catalytic activity of $\gamma$-glutamyltransferase in urine was within the control group values, whereas the catalytic activity of alkaline phosphatase was below the control group value.

Tab. 1 Urine $\mathrm{pH}$ and volume changes in experimental rats

\begin{tabular}{|c|c|c|c|}
\hline Day $^{\mathbf{a}}$ & & $\begin{array}{l}\text { Urine } \\
\mathrm{pH}\end{array}$ & $\begin{array}{l}\text { 18-h urine } \\
\text { volume (ml) } \\
\overline{\mathbf{x}} \pm \mathrm{SD}\end{array}$ \\
\hline $\begin{array}{c}\text { Control group } \\
0\end{array}$ & $\begin{array}{r}(n=6) \\
1(n=8) \\
4(n=7) \\
10(n=8)\end{array}$ & $\begin{array}{r}6.0 \\
5.0 \\
5.0 \\
10.5\end{array}$ & $\begin{array}{l}3.06 \pm 1.8 \\
2.10 \pm 1.1 \\
9.20 \pm 4.2^{*} \\
1.58 \pm 0.5\end{array}$ \\
\hline
\end{tabular}

a days after the first application of valproate

$* \mathrm{p}<0.05$ 


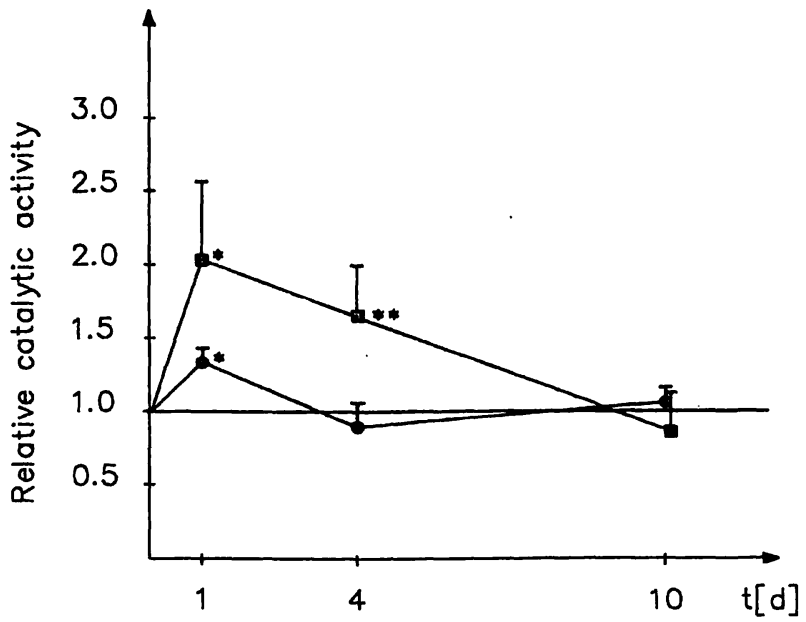

Fig. 1 Effect of sodium valproate on the catalytic activity of alanine aminopeptidase in rat urine and kidney brush border membrane vesicles. Changes in enzyme catalytic activity are presented as relative activities in comparison to control group values.

Control group activities in urine ( $\square-\square)$ and kidney brush border membrane vesicles $(0-0)$ were: $0.036 \pm 0.01 \mathrm{U} / 18 \mathrm{~h}$ volume and $299.5 \pm 55 \mathrm{U} / \mathrm{mg}$ protein, respectively; ${ }^{*} \mathrm{p}<0.05$

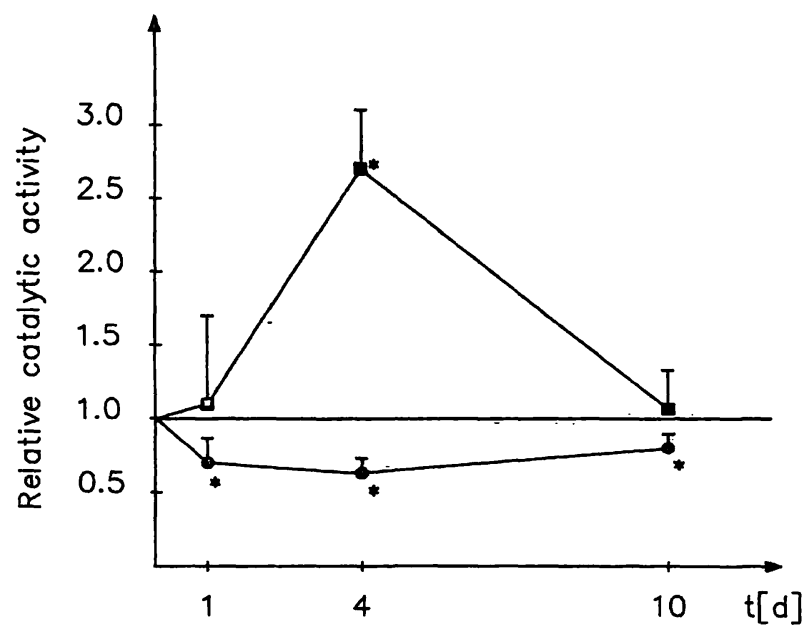

Fig. 2 Effect of sodium valproate on the catalytic activity of $\gamma$ glutamyltransferase in rat urine an kidney brush border membrane vesicles. Changes in enzyme catalytic activity are presented as relative activities in comparison to control group values.

Control group activities in urine $(\mathbf{m}-\mathbf{a})$ and kidney brush border membrane vesicles $(0-\bullet)$ were: $0.685 \pm 0.13 \mathrm{U} / 18 \mathrm{~h}$ volume and $12955 \pm 2142 \mathrm{U} / \mathrm{mg}$ protein, respectively; ${ }^{*} \mathrm{p}<0.05$

The activity of $\gamma$-glutamyltransferase in isolated renal brush-border membrane vesicles was decreased about 0.30 -, 0.40 - and 0.18 -fold on days 1,4 and 10 , respectively, whereas the activity of alkaline phosphatase was significantly increased (from 1.45 -fold on days 1 and 4 to 2.18 -fold on day 10 of the trial; $\mathrm{p}<0.05$ ).

\section{Discussion}

A relatively small number of adverse effects of sodium valproate on kidney cells have been reported in the literature $(10,11)$. On the other hand, numerous effects of

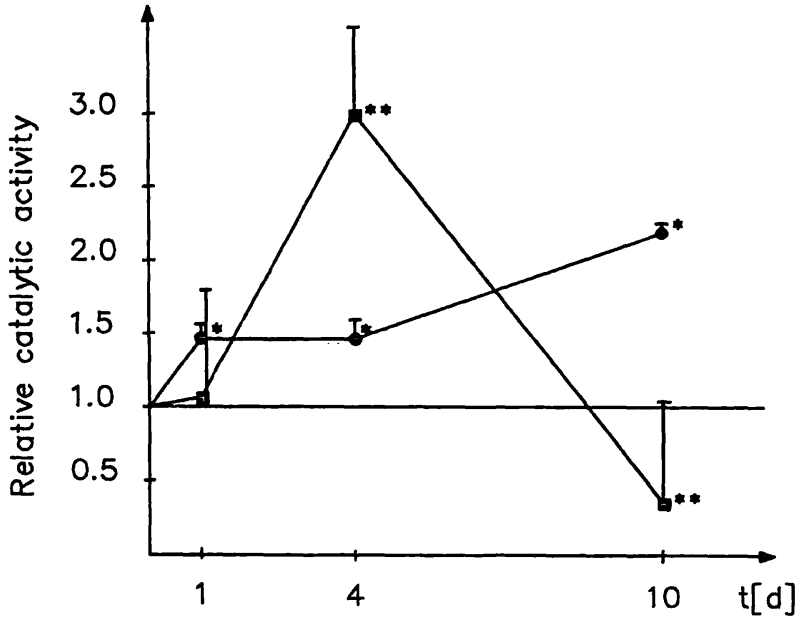

Fig. 3 Effect of sodium valproate on the catalytic activity of alkaline phosphatase in rat urine an kidney brush border membrane vesicles. Changes in enzyme catalytic activity are presented as relative activities in comparison to control group values.

Control group activities in urine $(\mathbf{D}-\mathbf{\square})$ and kidney brush border membrane vesicles $(0-0)$ were: $0.10 \pm 0.06 \mathrm{U} / 18 \mathrm{~h}$ volume and $2485 \pm 178 \mathrm{U} / \mathrm{mg}$ protein, respectively; ${ }^{*} \mathrm{p}<0.05 ;{ }^{* *} \mathrm{p}<0.01$

the drug on kidney metabolism, such as increased metabolism of glutamine and increased synthesis of ammonium, significantly decreased renal absorption of lactate and pyruvate, inhibition of long-chain fatty acid oxidation, decreased synthesis of carnitine in the kidney, inhibition of ketogenesis, mitochondrial dysfunction, etc., have been reported $(9,21)$. All these changes appear to support the hypothesis that treatment of epilepsy with sodium valproate might damage kidney cells, depending on the duration of therapy, dosage and individual susceptibility.

For the following, we focused our attention on the activity of enzymes localized on the renal proximal tubule cells: according to Warter et al. (8), sodium valproate, a short-chain fatty acid, affects the structure of the cell membrane; by histologic examination of the renal tissue from patients with interstitial nephritis due to sodium valproate, China-Young Lin \& Huang Ching (11) found dense material deposited in the basal membrane of tubular cells; considerable amounts of sodium valproate are metabolised in the cells of proximal and distal tubules of the kidney (22).

The investigated enzymes are known as surface enzymes or integral constituents of the brush-border membrane cells of the kidney proximal tubules. Their urinary excretion is considered to be a useful early indicator of kidney alterations (13).

The time-dependent and significantly elevated catalytic activities of the three enzymes in the urine of experimental animals pointed to an adverse action of the drug on the kidney cells. The catalytic activity of alanine aminopeptidase was significantly increased as early as 
the first day after sodium valproate administration, which is consistent with the finding that the enzyme is readily released from the surface of the cell membrane (23). A relatively early urinary excretion of alanine aminopeptidase was also observed by Holmes et al. (24) in their study of the coordinated release of urinary lysosomal and brush-border enzymes following renovascular surgery. The authors conclude that cell components, including enzymes, are affected by transitory pathophysiologic changes in the kidney. We postulate that the decreased enzyme activity in urine after 10 days of treatment was probably due to a significant change in urine $\mathrm{pH}$. By urine dialysis, we eliminated the inhibitors of alanine aminopeptidase and other enzymes. However, it is known from the literature (25) that enzymatic activity can be decreased by prolonged urine retention in the bladder, as well as by urine collection over a prolonged period of time, as in our experiment $(18 \mathrm{~h})$. The use of sodium valproate is associated with an increased formation of ammonium ions in the body. Thus, the above data, and the fact that ammonium ions are known to inhibit alanine aminopeptidase ((26), appears to invalidate this enzyme as a diagnostic indicator of adverse changes in kidney cells during the administration of this drug.

Although the incorporation of $\gamma$-glutamyltransferase into the cell membrane lipid matrix is, according to the literature, weaker than that of alkaline phosphatase (23), marked enzymuria, together with notable polyuria, was observed concurrently for both enzymes on day 4 to the drug administration. These results are consistent with the observations of Jung et al. (27), who found that an increased water intake, i. e. increased diuresis in normal subjects, resulted in an increased excretion of soluble forms of the brush-border membrane enzymes, whereas the excretion of particulate forms was independent of diuresis. Therefore, in our future studies with sodium valproate, it might prove useful to determine both forms of $\gamma$-glutamyltransferase and alkaline phosphatase, or to express the enzyme catalytic activities in relation to cre- atinine concentration, which is one of the recommended ways of expressing urinary enzyme catalytic activities (25). The observed normalization of urine enzyme activities after 10 days may reflect the adaptation of renal cells to the presence of the drug. These changes in the enzyme catalytic activities are consistent with data obtained in similar studies of renal cell impairment (28). Most of these studies show an intermittent increase in urinary enzyme activities, depending on the study duration or the concentration of the potentially toxic substance.

Whereas the activity of $\gamma$-glutamyltransferase in isolated renal brush-border membrane vesicles decreased as expected, the marked increase in the activity of alkaline phosphatase was probably due to the enhanced synthesis of enzyme multiple forms in the renal tissue (intestinallike and hepatic types) and subsequent excretion in the urine. Thus, Pfleiderer et al. (29) found an increased amount of the intestinal-like forms of alkaline phosphatase in the urine from subjects receiving potentially toxic drugs.

In our experiments with rats, $200 \mathrm{mg} / \mathrm{kg}$ body weight sodium valproate per day appeared to cause transient changes in renal cell membranes, resulting, over a period of 10 days, in increased enzymuria of the specific enzymes, polyuria, and changes in urine $\mathrm{pH}$. Proteinuria, microhaematuria and histological alterations due to the use of sodium valproate have also been demonstrated in humans (11). Thus, the data presented appear to suggest that the state of renal cells should be monitored during therapy with sodium valproate. This is especially important if it is given over a long period, during which not only transitory but also more severe damage to the renal tubular cells can be expected to occur. As urinary enzymes are very early indicators of adverse renal cell changes, the present results indicate that the determination of urinary catalytic activities of $\gamma$-glutamyltransferase and alkaline phosphatase may be useful for monitoring patients for adverse effects of sodium valproate treatment.

\section{References}

1. Egger J, Brett EM. Effect of sodium valproate in 100 children with special reference to weight. Brit Med J 1981; 283:57781.

2. Marescaux C, Warter JM, Laroye M, Rumbach L, Micheletti $\mathrm{G}$; Koehl C, et al. Le valproate de sodium: une drogue hyperammoneminate - Etude chez l'epileptique et chez le volontaire sain. J Neurol Sci 1983; 58:195-209.

3. Mortensen PB, Hausen HE, Pedersen B, Hartman-Andersen F, Husted SE. Acute valproate intoxication: biochemical investigations and hemodialysis treatment. Int J Clin Pharmacol Ther Toxicol 1983; 21:64-8.

4. Murphy JV, Marquardt K. Asymptomatic hyperammonaemia in patients receiving valproic acid. Arch Neurol 1982; 39:591-2.

5. Williams CA, Tiefenbach S, McReynolds JW. Valproic acidinduced hyperammonaemia in mentally retarded adults. Neurology $1984 ; 34: 550-3$.

6. Turnbull DM, Bone AJ, Bartlett K, Koundakjian PP, Sherratt HSA. The effect of valproate on intermediary metabolism in isolated rat hepatocytes and intact rats. Biochem Pharmacol 1983; 32:1887-92.

7. Baverel G, Durozard D, Martin G. Mechanisms of valproatemediated stimulation of ammonia genesis in isolated rat kidney cortex tubules. Kidney Int 1986; 29:350. 
8. Warter JM, Brandt C, Marescaux C, Rumbach L, Micheletti G, Chabrier G, et al. The renal origin of sodium valproate induced hyperammonaemia in fasting humans. Neurology 1983: 33:1136-40.

9. Rengel-Aranda M, Gougoux A, Vinay P, Lopez-Novoa JM. Effect of valproate on renal metabolism in the intact dog. Kidney Int 1988; 34:645-54.

10. Lenoir G-R, Perignon JL, Broyer M. Valproic acid: a possible cause of proximal tubular renal syndrome. J Pediat 1981; 98:503-4.

11. Ching-Yuang $L$, Chiang $H$. Sodium valproate-induced interstitial nephritis. Nephron 1988; 48:43-6.

12. Cotariu D, Zaidman JL. Valproic acid and the liver. Clin Chem 1988; 34:890-7.

13. Jung $K$, Burchardt U. Harnenzyme im Experiment und in der Klinik. J Clin Chem Clin Biochem 1987; 25:823-8.

14. Biber J, Streger B, Hasse W. A high yield preparation for rat kidney brush border membranes. Different behavior of lysosomal markers. Biochim Biophys Acta 1981; 647:1167-76.

15. Haschen RJ. Alaninaminopeptidasen, Biochemie und diagnostische Bedeutung. Leipzig: Johann Ambrosius Barth, 1972.

16. Bowers GN, McComb RD. Measurement of total alkaline phosphatase activity in human serum. Clin Chem 1975; 21:1988-95.

17. Szász G. A kinetic photometric method for serum gamma-glutamyltranspeptidase. Clin Chem 1969; 15:124-36.

18. Sampson EJ, Baird MA, Burtis CA, Smith EM, Witte DL, Bayse DD. A coupled-enzyme equilibrium method for measuring urea in serum: optimisation and evaluation of the AACC Study Group on Urea Candidate Reference Method. Clin Chem $1980 ; 26: 816-26$.

19. Bradford MM. A rapid and sensitive method for the quantitation of micro-gram quantities of protein utilising the principle of protein dye binding. Anal Biochem 1976; 82:248-54.

20. Samuels ML. Statistics for the life sciences. San Francisco: Maxwell Macmillan International Editions, 1991:242-4.

21. Matsuda I, Ohtani I, Ninomiya N. Renal handling of carnitine in children with carnitine deficiency and hyperammonaemia associated with valproate therapy. J Pediat 1986; 109:131-4.
22. Aly MM, Abdel Latif AA. Studies on distribution and metabolism of valproate in rat brain, liver and kidney. Neurochem Res $1980 ; 5: 1231-42$.

23. Li Hsu BY, McNamara DP, Schlesinger H, Pepe LM, Marshall $\mathrm{CM}$, Segal S. Ease solubilisation of five marker enzymes in three preparations of rat brush border membranes. Enzymes $1980 ; 25: 170-81$.

24. Holmes RP, Craddock G, Espeland MA, Assimos DG, Dean RH. A lack of coordination in the release of urinary lysosomal and brush border enzymes following renovascular surgery. Clin Chim Acta 1989; 186:1-10.

25. Jung K. Enzyme activities in urine: how should we express their excretion? Eur J Clin Chem Clin Biochem 1991; 29:725-9.

26. Mattenheimer H, Frölke W, Grötsch H, Simone Z. Identification of inhibitors of urinary alanine aminopeptidase. Clin Chim Acta 1986; 160:129-35.

27. Jung K, Schulze G. Diuresis-dependent excretion of multiple forms of renal brush border enzymes in urine. Clin Chim Acta 1986; 156:77-84.

28. Price RG, Whiting PH. Urinary enzymes and nephrotoxicity in humans. In: Jung $H$, Mattenheimer $H$, Burchardt $U$, editors. Urinary enzymes in clinical and experimental medicine. Berlin-Heidelberg-New York: Springer Verlag, 1992:204-21.

29. Pfleiderer G, Baier M, Mondorf AW, Stefanescu T, Scherberich JE, Müller H. Change in alkaline phosphatase isoenzyme pattern in urine as possible marker for renal disease. Kidney Int $1980 ; 17: 242-9$.

Professor Ivana Čepelak, Ph. D. Institute of Medical Biochemistry School of Pharmacy and Biochemistry U1. Ante Kovačića 1 41000 Zagreb Croatia 
